\title{
Early theoretical concepts in soil fertility
}

\author{
C. T. de Wit \\ Department of Theoretical Production Ecology, Agricultural University, Wageningen, \\ the Netherlands
}

\section{Early agricultural methods}

In steady natural ecosystems, a balance between growth and decay is maintained. A few people who restrict themselves to gathering the essentials of food, clothing and shelter may easily form part of such a steady system.

To avoid the hardships of such life, it may have been a small step to switch to primitive agricultural practices. But then, the balance between growth and decay that is established in natural systems is disturbed by the harvest operation which moves minerals and nitrogen away from the field. Thus an unsteady system results with year-by-year decreases in yield until the harvest hardly balances the input of seeds.

In principle there are two ways to grow crops and still to avoid the disaster of decreasing yields. It is possible to abandon the field for at least 15 years after a few years and leave it to nature to restore the fertility. This shifting cultivation has been and is widely practiced. This is a sound system as long as the population is so small that the periods of recovery are sufficiently long compared with the periods of agricultural use. With increasing population it is necessary to return too frequently to the same field, leaving too less time for recovery. Ultimately the periods of recovery are then so short that the system breaks down.

To ensure then for the seeds a yield return that justifies the human effort, one must adopt other systems of management, such as that developed to a high degree of perfection in the 18th century in Western Europe. Marginal lands were then used for livestock with emphasis on manure production for the arable land, and all organic waste was carefully returned to the field. Moreover, cash crops were alternated with forage crops to promote the restoration of fertility.

Several scientists in the 18th century and the first half of the 19th century became interested in agricultural problems, and theories were developed to describe the problem of maintaining and increasing the fertility of the fields. These theories emphasize dynamic aspects of the problem, so often neglected in our present reductionist approach.

\section{The humus theory}

At first, an attempt by Albert Thaer (Fig. 1) to develop a theoretical basis for crop husbandry systems practiced in his time will be discussed. This attempt has been published in his classic 'Grundsätze der rationellen Landwirtschaft' (1809).

Thaer knew the observation of de Sausure that in light plants absorb carbon dioxide from the air, that they grow poorer in soil leached with warm water than on unleached soil, and that with warm water a brown substance, 'humus', is removed from the soil. From such facts, he postulated that any sufficienly rotted organic material contains all the substances needed for growth of the plant. 


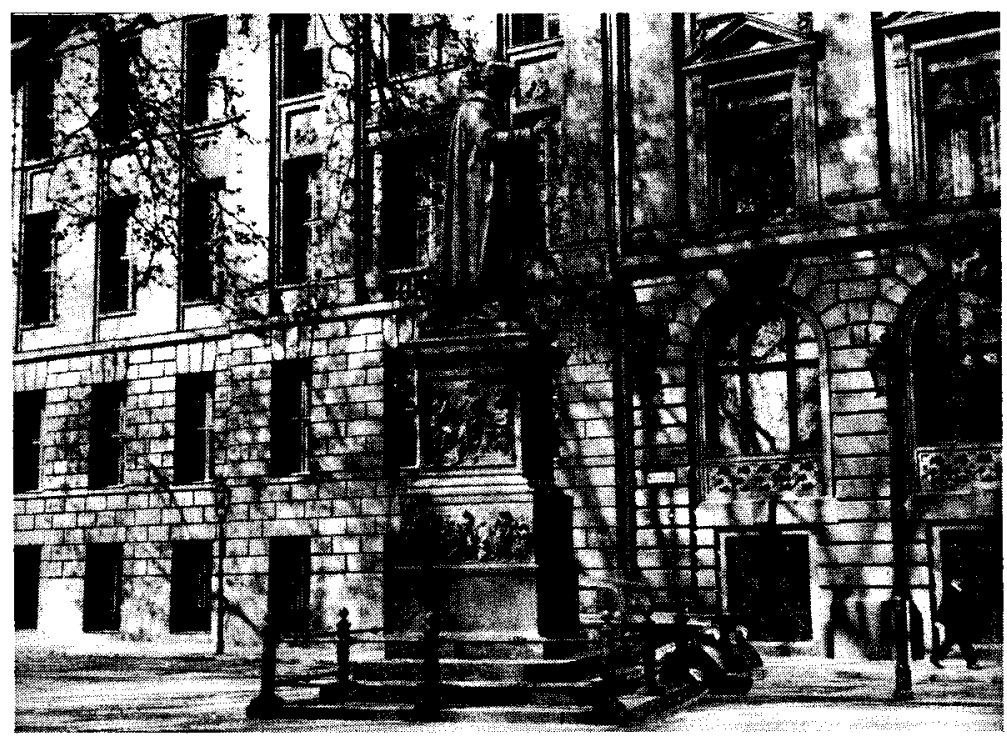

Fig. 1. The statue of Albrecht Thaer in Berlin before 1945. The statue seems to be stored now in some cellar of some museum. On the panels are reliefs of his pupils, one of them being von Wulffen. (Photo: Landesbildstelle, Berlin.)

Inspired by the usefulness of the thermometer to characterize the abstract notion of heat as a 'quantity', he scaled the fertility of the soil also from zero to one hundred. Then he assumed rather arbitrarily that the amount of fertility removed from the soil by the harvest of one bushel of rye per acre equalled 5 degrees. Based on his experience, he then assumed that with the removal of a bushel of wheat, barley and rye $6.5,3.5$ and 2.5 degrees fertility were removed, respectively, and that the fertility increased by 10 degrees for each fallow year and for each cartload of manure per acre and by 5 degrees for each year of cultivation of clover or grass. Moreover he assumed that the fertility necessary to obtain any yield at all equalled 40 degrees and that with an increase of fertility of ten degrees the yield of rye increased by 0.6 bushel per acre.

Hence to maintain the fertility of a field that yielded in the first year 10 bushels of rye per acre, in the second year 9 bushels of barley and was fallowed in the third year, it was necessary to supply $10 \times 2.5+9 \times 3.5-10=62.5$ degrees of fertility, or 6.25 cartloads of good manure during these three years.

Obviously Thaer's theory consisted of some naive rules of thumb formulated on the basis of practical experience. Thaer was aware of this and was convinced of the necessity of further chemical research on the nature of the humus.

\section{The stationary law}

One of Thaer's pupils, Carl von Wulffen from Pietzpull (1785-1853, Fig. 1) recognized the primitive state of the natural sciences and started out to show that farm management could be understood and improved upon only by studying in detail the dynamics 
of the system. It is still worthwhile to consider this theory because it is the first example of a careful system analysis, long before this term was invented, and because it shows clearly one of the dangers of this at present fashionable approach to problems we do not understand. Von Wulffen's first articles were written during the many idle hours spent in the Prussian army that fought Napoleon at the end of his Russian adventure. They are difficult to read because he formulated all relations in the terminology of Thaer. By far the best are his article 'Ideeen zur Grundlage einer Statik des Landbaues' which appeared in 1823 in the Mogliner Annalen, and the first book, 'Die Vorschule der Statik des Landbaues' that appeared in 1830. The disappointment of a sadder and wiser man is reflected in his last book, 'Entwurf einer Methodik zur Berechnung der Feldsysteme', which appeared in 1847, seven years after von Liebig published all the evidence that plants needed only water, minerals and nitrogen from the root medium and killed with intelligence and sarcasm the theory that humus as such is a plant nutrient.

Von Wulffen proved at first that the arbitrary scaling in degrees as introduced by Thaer was not necessary. For his purpose he distinguished two quantity parameters: the yield and the 'Reichtum' (richness) of the soil and one intensity parameter: the 'Thätigkeit' (yield coefficient) which he joined by his 'Statische Gesetz' or Stationary Law:

\section{Yield $=$ Thätigkeit $\times$ Reichtum or $\mathrm{Y}=\mathrm{T} \times \mathrm{R}$}

The 'Reichtum' of the soil is a measure of the total yielding capacity of the soil and the 'Thätigkeit' the fraction of this 'Reichtum' that is each year removed by the harvest. The 'Reichtum' is therefore expressed in the same unit as the yield. Von Wulffen remarked that the 'Reichtum' and 'Thätigkeit' of any soil could be calculated by considering two successive harvests. For instance, if a field of rye yields $2000 \mathrm{~kg} / \mathrm{ha}$ during the first year and $1600 \mathrm{~kg}$ during the second, then holds for the first year: $2000=T \times R$ and for the second year: $1600=T \times(R-2000)$, so that $R=$ $10000 \mathrm{~kg} \mathrm{ha}^{-1}$ and $\mathrm{T}=0.2$.

This relation between yield 'Reichtum' and 'Thätigkeit' is graphically presented in Fig. 2 in which the 'Reichtum' in the $(n+1)$ th year is given as a function of the 'Reichtum' in the n-th year. In situations of zero 'Thätigkeit', the activity lines coincide with the 45 degree line, the yield is zero and the 'Reichtum' does not change. To

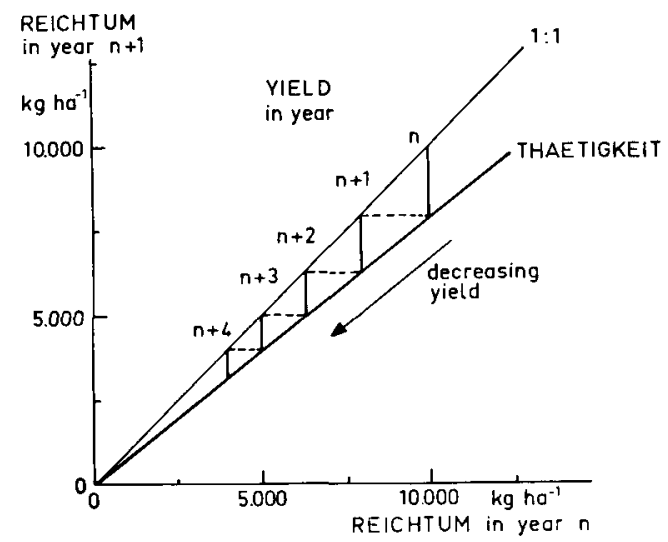

Fig. 2. A graphical presentation of the exponential decay of yield and 'Reichtum' by cropping, according to von Wulffen. 
characterize a 'Thätigkeit' of 0.2 , a line is drawn with a slope of 0.8 . The successive yields, here starting at a 'Reichtum' of $10000 \mathrm{~kg} \mathrm{ha}^{-1}$, may now be read by following the broken line to the origin. Obviously, the yields of a field decrease according to the theory of von Wulffen exponentially in situations where nothing is added to the richness of the soil.

To compare two crop species, von Wulffen advised to grow them side by side for two years. If then the 'Reichtum' expressed in $\mathrm{kg}$ rye ha-1 equals 2000 and in $\mathrm{kg}$ oats hat 2400 , it can be concluded that 1 unit of rye equals 1.2 units of oats. Likewise the 'Thätigkeit' of two species can be compared in this way.

Ensuing from von Wulffen's work, many experiments were done to determine the equivalent value of the most important crops, with rye as a standard. As often the original supposition that these values were practically independent of wheather and soil type was not confirmed, and this complicated the analysis.

The 'Reichtum' of the soil could be increased again by adding manures, by fallowing and by growing fodder crops and green manures, especially clover. Now it was well known that the yield increase due to a certain amount of manure depended to a large extent on its quality and the properties of the soil. Von Wulffen proposed no longer to express the amount of manure as cartloads but as the weight of the various products fed to the livestock producing the manure: in $\mathrm{kg}$ straw, $\mathrm{kg}$ rye seed, $\mathrm{kg}$ hay and so on. Even now this seems highly sensible.

To cope with the problem of why one soil needed more manure to increase its 'Reichtum' than an other, he introduced the 'Gattung' (manure coefficient) of the soil. The 'Gattung' of the soil was supposed to be 1 when it was possible to return to the original 'Reichtum' by applying the manure, obtained by feeding the harvest to animals. Depending on the 'Gattung' being lower, equal or larger than one, the soil was classified as 'bedürftig', 'gesund' or 'kräftig' (needy, healthy or strong). Moreover, he classified the soils according to the influence of temperature and water status on the 'Thätigkeit'. A soil was 'kalt' (cold) when an increase in temperature and a decrease in moisture content increased the 'Thätigkeit' and was 'hitzig' (hot) when conditions were the reserve. Von Wulffen adapted what may be called at present an 'alternative terminology'.

What are the successive yields on a hectare with a 'Thätigkeit' and 'Gattung' equal to 0.2 and 1, respectively, and with zero 'Reichtum', when every year an amount of manure is added equal to $2000 \mathrm{~kg}$ rye equivalents? The answer to this question can be given most conveniently by means of Fig. 3, in which the 'Reichtum' in two successive years is given again along the axis. The yearly supply of 'Reichtum' is equal to the vertical distance between the lines 1 and 2 and the yield equal to the vertical distance between line 1 and 3 , the slope of line 3 being determined by the 'Thätigkeit'. Starting from a 'Reichtum' of $0 \mathrm{~kg} \mathrm{ha}^{-1}$, the yield during the first year equals $0.2 \times$ $(0+2000)=400 \mathrm{~kg} \mathrm{ha}^{-}{ }_{1}$ and the increase in 'Reichtum' $2000-400=1800 \mathrm{~kg}$ $\mathrm{ha}^{-1}$. Hence the next year the 'Reichtum' is $1600 \mathrm{~kg} \mathrm{ha}^{-1}$ and the yield $0.2 \times$ $(1600+2000)=720 \mathrm{~kg} \mathrm{ha}^{-1}$ and the increase in 'Reichtum' $1280 \mathrm{~kg} \mathrm{ha}{ }^{-1}$. These changes are graphically presented in the figure to make clear that ultimately the yield stabilizes at $2000 \mathrm{~kg} \mathrm{ha}^{-1}$ and the 'Reichtum' of the soil at $10000 \mathrm{~kg} \mathrm{ha}^{-1}$ after and $8000 \mathrm{~kg} \mathrm{ha}^{-1}$ before the yearly fertilization. This ultimate value is independent of the original fertility status of the soil, as is illustrated in the figure by starting the process at an initial 'Reichtum' of $15000 \mathrm{~kg} \mathrm{ha}^{-1}$.

Provided that the 'Thätigkeit' and 'Gattung' of the soil are known from experimentation, this 'Beharrungspunkt' (stationary point) can be calculated for every crop 


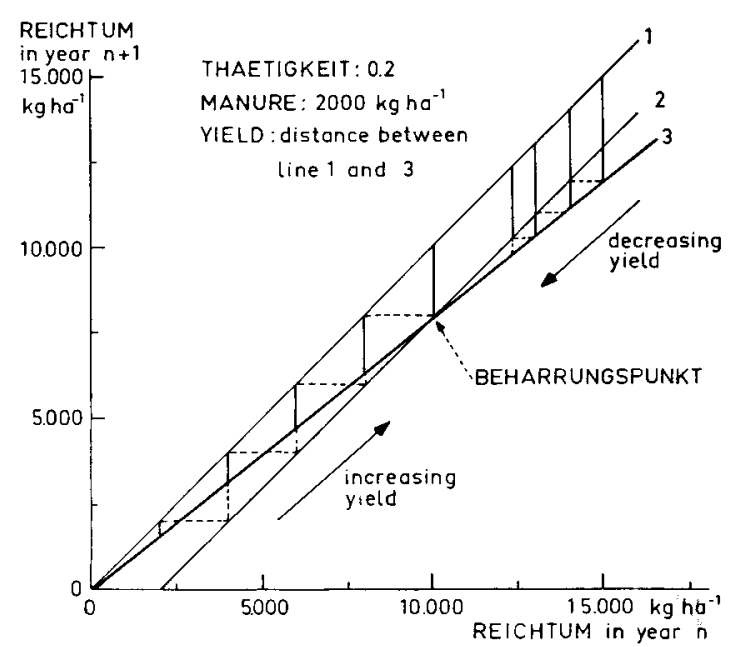

Fig. 3. A graphic presentation of the approach to an equilibrium situation in a case where each year the same amount of manure is given and the same crop is grown.

rotation and fertilizing scheme, provided that all inputs and outputs are carefully accounted. In von Wulffen's view, the farm management had to be directed to the maintenance of the 'Beharrungspunkt' on such a level that the grain yields were as high as possible without running the risk of too much straw production or lodging.

On basis of this optimalization criterium he was able to calculate for every farm the amount of grassland needed to provide the manure needed to compensate for the amount of products taken from the farm. Within this framework, it was possible either to create a farm where the 'Reichtum' of the soil was high and the 'Thätigkeit' low, or the reserve.

Von Wulffen's concept wat at his time referred to as 'Das statische Gesetz' (the stationary law), although his theories were very much of a dynamic character and applied by von Wulffen to compute time courses of 'Reichtum' and yield of the various fields of a farm under various management situations. These calculations are of historic interest only.

\section{Two views of soil fertility}

Thaer stimulated research on soil fertility and farm management in two directions, which developed independently in the first part of the 19th century.

On one hand, there was von Wulffen who emphasized the dynamic aspects of the problem of maintaining soil fertility and who advocated that it was unnecessary and practically impossible to use natural science concepts, and that enrichment and exhaustion of the soil could be determined by carefully accounting inputs and outputs of each field and the farm as a whole. His great influence on farm management during the first half of the 19th century is illustrated by the many excellent accounts that have been made of big farms during this time with the special purpose to evaluate von Wulffen's concept and to determine all his coefficients.

On the other hand, the natural sciences gained momentum, culminating in Sprengel's 
book 'Die Lehre vom Dünger oder Beschreibung aller bei der Landwirtschaft gebräuchlichen vegetabilischen, animalischen und mineralischen Düngmaterialen, nebst ihre Erklärung ihrer Wirkungsart' which appeared in 1839, one year before von Liebig advocated essentially the same views in a much better written book. Sprengel showed that plants consist of 15 elements and that they produce organic matter under influence of light, heat water and electricity out of anorganic material obtained from the air and the soil. He introduced also the 'law of the minimum' which stated that to increase the yield it was only necessary to apply that element that was the least available.

One would assume that these facts would have convinced von Wulffen and his disciples that they had betted on the wrong horse. But this was not the case because the new concepts were not too sound from the practical standpoint.

In the first place, it was assumed by the natural scientists that to maintain soil fertility, it was sufficient to replace again the minerals that were removed from the soil by the process of harvesting. Important phenomena like the fixation of phosphate and fixation and leaching of potassium were not sufficiently recognized. Implicitly it was assumed that the 'Gattung' of the soil was always 1 , which was obviously not true, as shown by the advocates of the 'stationary law'.

In the second place, it was assumed by von Liebig that nitrogen, like the carbon dioxyde, was obtained from the air and was never limiting, so that fertilization with $\mathrm{N}$-containing nutrients was considered unnecessary. This opinion was opposed by Lawes and Gilbert in England and very convincingly disproven by Wolff in his small brochure 'Die Erschöpfung des Bodens durch die Kultur' (1856) in which was shown on basis of fertilizer experiments and crop analyses that under normal agricultural practice the exhaustion of the soil is in the first place due to a lack of nitrogen compounds suitable for plant use and that aiming only at the return of mineral elements removed with the harvest products is not sufficient at all.

Von Wulffen's dynamic theories accounted implicitely for the nitrogen balance on the farm, be it in a very rudimentary way, and that is the reason why his views retained acceptance during a great part of the 19 th century, in spite of his disregard for natural science.

\section{References}

Drechsler, Gustav, 1869. Die Statik des Landbaus: Geschichte, Kritik und Reform, Göttingen.

Liebig, Justus von, 1855. Die Grundsätze der Agricultur-Chemie mit Rücksicht auf die in England angestellten Untersuchungen, 2nd ed. Braunschweig.

Sprengel, C., 1839. Die Lehre vom Dünger, oder Beschreibung aller bei der Landwirtschaft gebräuchlichen vegetabilischen, animalischen und mineralischen Düngmaterialen, nebst ihre Erklärung ihrer Wirkungsart. Leipzig.

Thaer, Albrecht, 1809. Grundsätze der rationellen Landwirtschaft.

Wolff, E., 1856. Die Erschöpfung des Bodens durch die Cultur. Leipzig.

Wulffen, Carl von, 1823. Ideeen zur Grundlage einer Statik des Landbaues. Mogliner Annalen, Band XI. Wulffen, Carl von, 1830. Die Vorschule der Statik des Landbaues. Magdenburg.

Wulffen, Carl von, 1847. Entwurf einer Methodik zur Berechnung der Feldsysteme. Berlin. 